\title{
ФЕМIHICТИЧНI СТУАIÏ
}

https://doi.org/10.33608/0236-1477.2022.01.82-98

УАК 821.161 .2

Олександр АВЕРБУХ, Аоктор філософії

А^ьбертський університет

200 Arts Building Edmonton, T6G 2E6

e-mail: averbuchalex@gmail.com

ORCID https://orcid.org/0000-0003-0721-6958

\section{ОРІЕНТААІЗАЦІЯ ЖІНОЧНОСТІ: ПОНЯТТЯ НЕЧЕСТИВОСТІ В УКРАЇНСЬКІЙ МОАЕРНІСТСЬКІЙ $\Lambda$ ITEPATУPI}

У статті аналізується взаємозв'язок жіночності та етнічної іншості в украӥнській модерністській літературі. Розглядається закріплення «гріховної» чужості жінки в маскулінній традицї через сексуальну та культурну диференціацію подібно до «зінакщення» орієнталізованих етнічних груп Східної Європи, здебільшого євреїв, ромів і татар, що передбачало іхню концептуальну фемінізацію. Ао аналізу залучені твори, в яких жінки постають демонічно-вампіричними спокуснииями й такими, які руйнуюоть етно- та андрочентричний монокультуралізм модерністської доби.

Ключові слова: етнічне іншування, модерністська література, мізогінність, жіноче письмо, гендер.

Репрезентації етнічного Іншого в українській модерністській мітературі не раз ставали предметом досліджень. Про зображення в художніх творах євреїв писали Григорій Грабович [1, 238-258] та Мирослав Шкандрій [28], про образ ромів - Тетяна Сукаленко [13] і Євген Крамар $[6,48-50]$, художню репрезентацію татар досліджувала Галина Єрмоленко [31]. Утім, у наукових дискусіях увага переважно зосереджувалась кише на загальних рисах етнообразів, які цілком укцадацися в панівні уявлення про те, як у мітературі формується інакшість. Чужість Іншого зазвичай не розглядали за межами суто етнічних аспектів, типових Аля цілої нації, не вирізняли категорій іншуван-

Ц и т у в а н н я: Авербух О. Орієнталізація жіночності: поняття нечестивості в українській модерністській мітературі // САово і Час. 2022. № 1 (721). C. 82-98. https://doi.org/10.33608/0236-1477.2022.01.82-98 
ня, які Аодавалися до націонацьного сприйняття чужинця. У наукових студіях мало уваги приділено зв'язку між фемінністю та інакшістю (етнічною щодо українців).

У творах, про які йтиметься у статті, орієнтацізована фемінність ${ }^{1}$, сексуальність і нечестивість ${ }^{2}$ пов'язані з чуттєвими втіхами й насолодами, забороненими в домінантній культурі. Українські митці-модерністи, залучаючи у свою творчість теми «Сходу», шукаци розради й розваги у вимірі орієнтальної фемінності, на яку вони могли вільно проєктувати власні «заборонені» бажання.

У європейській культурі гріховність довгий час пов'язували з етнічним або сексуальним Іншим. Інакшість формувалася так, що «традиційних єресіархів» - жінок, гомосексуалів, представників інших віросповідань або національностей - орієнталізуваци й демонізували $[17 ; 19 ; 22]$. Таких Інших, затиснутих у категорію не мише культурної, а й біологічної

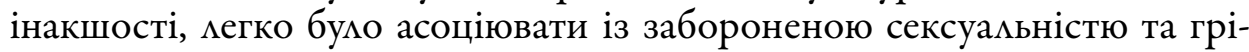
ховністю $[20,160-174 ; 23,150-162 ; 25,11-24]$. Щодо жінок, то їм приписували (як і етнічним Іншим та гомосексуалам) моральну та фізичну нечестивість (зокрема, внаслідок уявлень про жіночу розпусність ї уважаци небезпечними через венеричні хвороби [24]).

Теми занепаду слов'янської / православної / маскулінної «раси» були культурними кодами модернізму, відображаци страх націонацьного, расового, релігійного «забруднення» неслов'янами або нехристиянами і перегукувалися з мізогінним уявленням про жіночність як Ажерело духовного та фізичного занепаду. АосліАники українського модернізму часто проводять паралелі між опозиційними парами: модернізм / українофільство, фемінність / маскулінність. Зокрема, Тамара Гундорова припускає, що модерністська естетика стала відходом від репресивної українофільської ідеології народництва, «одного верховного Батька - законодавця традиції» $[4,144]$. Соломія Павличко зауважувала, що утверАження модерністських цінностей та руйнування попередніх Аискурсів, особливо народництва, здійснювали жінки [10, 68].

Орієнталізована жіночність, а також привнесені нею в український модернізм амбівалентність і невизначеність жіночих образів стали маркером етнічних страхів і природженої гріховності. Останню традиційно пов' язували з femme fatale, а також зі схожими образами провинного янгола та спокусниці, призвідниками морацьної, сексуальної, націонацьної й релігійної трансгресії та передвісниками кризи патріархацьності й репродуктивності. За Максимом Тарнавським, український модернізм пов'язував жіночу гріховну природу із загрозою денаціонацізації, розхитуванням уявлень про стабільне етнічне середовище та зрадою патріар-

\footnotetext{
${ }_{1}$ Орієнталізація - накмадання на протагоністок фізичних та культурних рис, характерних «орієнтальним», «екзотичним» народам (переважно близькосхідного похоАження, але не тільки), з метою культурного, соціологічного та фізичного іншування.

2 Нечестивий - такий, який ображає щось святе, порушує узаконені релігією норми, моральні переконання; або гріховний, який «забруднює» собою культуру, націю, суспікьство.
} 
хального спадку [29, 34-38]. С. Павличко підкреслювала притаманну Ользі Кобимянській амієнацію віА «ріАного грунту» [10, 51]. Т. Гундорова аналізує жіночу сексуальність як «національну зраду» або «жіночий сепаратизм» [3, 224]. Яскравий прикмад орієнталізування в європейському модернізмі - образ femme fatale, наприкмад, у творах Оскара Вайлда («Саломея»), Стефана Мациарме («Іродіада»), Гюстава Моро («Саномея у в'язниці»). Надзвичайна еротична привабливість belle juive ${ }^{3}$ у цих творах вцастива також протагоністкам-ромкам і татаркам.

Метою цієї статті $є$ реконструкція могіки культурних умовностей, згіАно з якими в модерністській мітературі зображуваци жінок - етнічних чужинок, а також простеження, як деякі автори відходили віА цих умовностей. У АосАідженні використовуються методологічні принципи гендерних студій, психоаналізу та імагології.

Українські модерністи, на відміну від романтиків та реалістів, поступово трансформували архетипні мізогінні погляди, поширені в етнічному просторі, переосмислювали поняття національної чистоти і створювали новий образ жіночності й етнічного Іншого, чим забезпечили нові мітературні, соціальні та політичні ресурси Аля формування образу жінки.

\section{Відьма, інцестуальна коханка}

Головну героїню повісті О. Кобилянської «В неАілю рано зілця копала» (1908) зображено як віАьму. Ромку Мавру, ім'я якої грецькою означає «темношкіра», зараховано до категорії не тільки культурної, а й біологічної, майже нелюдської чужості, їй приписано морацьну та фізичну нечестивість, заборонену сексуальність, чужинську гріховну повеАінку. Через це іiі ізольовано віА соціуму, вона живе в землянці, «бурдей-колибі». ВіАомо, що чоловік Маври, Раду, змушував їі просити милостиню та ворожити. Опис Мавриного ворожіння й танців натякає на їі фізичний контакт 3 тими, хто платив їй за виступи. Іноді, ворожачи та співаючи перед заможними панами, вона отримуваца «брудні» гроші й за те, що гуляла з ними: «...а вона ворожила і співала до скрипки, а часом і гуляла... Там був один молодий боярин, що за циганську музику грубі гроші сипав... а часом з другими на коні... попри їх шатра вихром в пусту гнав. <...> Відтак посилав мене ще Раду в сусіАнє недалеке містечко по мимостині і ворожити - і то було найгірше» [5, 306]. Так Мавра завагітніла «білою» Аитиною.

Циганку зображено як Ажеремо морахьного, сексуацьного й етнічного занепаду села, втілення чужості, що проникца в українську громаду й таємно поширилася через ії нащадка. Ніхто не знає, що Гриць - Маврин син. Його усиновима заможна бездітна українська пара, юнак має успадкувати їхній маєток і стати чужинним господарем на українській землі, поставивши піА загрозу продовження українського етносу та успадкування головної цінності нації - землі. Аля неплідної українськості, що репрезентована названими батьками Гриця, він - єАина можливість

${ }^{3}$ La belle juive (з фр.: прекрасна єврейка) - прототип чарівної, розпусної єврейки, який був розповсюАжений переважно в європейській Аітературі XIX ст. 
«продовжити ріА» - фатально викоріняє його своєю неукраїнськістю. Майбутній шлюб Гриця з українкою Насткою - це втілення загрози матрилокальної екзогамії та міжетнічних стосунків як могічного проАовження проникнення Маври в сільську громаду. Цей шиюб створює зАовісну атмосферу, що навіює інстинктивний страх національного й кумьтурного геноциду та кастрації.

Ще одна спадкоємиця Мавриної чужості - Тетяна, яку та виростила в домі Іванихи Аубихи - Тетяниної біологічної матері. Іваниху Аубиху, подібно до бездітного подружжя, яке виховує Гриця, зображено якнездатну до материнства, майже черницю у своїй метафоричній безпліАності: вона не змогла передати Тетяні вмасну українськість. На початку повісті сказано, що в Іванихи Аубихи «знайшлася» Аитина (Гриця також було «знайдено» бездітним українським подружжям), хоч вона була вже немолода. Це зауваження підкреслює неоднозначність того, чиєю все-таки дитиною, спадкоємицею і нащадком $є$ Тетяна - чорнявої, темношкірої Маври чи немолодої та медве здатної на репродуктивність Аубихи. Посимює сумніви щодо материнства Іванихи Аубихи й вигляд Тетяни. ВіА Маври вона «успадковує» не тільки чужинську, таємничу й відьомську поведінку, а й орієнталізовану зовнішність: дівчина з «чорними густими бровами, що мукувато здіймаються, зціпившися наА носом, наА чорними задумчивими очима» $[5,331]$. Тетяна зростає на Мавриних циганських мегендах і знає ромську мову.

Чужість і відьомські знання, які Мавра передає Тетяні, символічно втілюються в сережках у формі півмісяця ( $є$ знаком орієнтальності), що переходять у родині Маври з покоління в покоління й сповнені демонічної сили. Прізвисько Тетяни - Туркиня - переносить манцюг спадковості з матеріальної символічної речі (сережок) на важливу Аля ідентичності Аюдини категорію - ім'я.

Тетяна постає втіленням етнічно іншої спокусливості та своєрідної гріховної жіночності, яку можна знайти у фолькморних зображеннях демонічної жіночої сексуацьності русалки, Баби Яги, Матінки Сирої Земмi, що часто мають і риси жіночої святості. Таке поєднання святості та гріховності - новаторство модерністської мітератури. Ряд Тетяниних іАентичностей (циганської, турецької та української) підсимює загрозу етнічної невизначеності, що багатошарово проступає за всіма масками.

Увага модернізму до масок і плинність ідентичностей заохочують порушувати табу і підАають сумніву іАею про стабільну етнічну приналежність (маски симвоцічно втілювали етнічні страхи й загрозмиві сими, що проступами за ними [Аив.: 26]). Обличчя без маски симвомізувало однозначну ідентичність, його вважали втіленням чистоти; обличчя в масці - втілення страху перед чужим і нечистим. Ці пере-

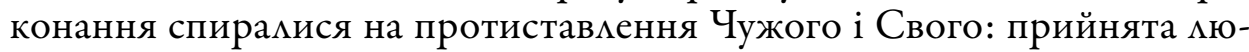
Аиною ззовні ідентичність піддаваца сумніву не тільки однозначність статі, а й часто етнічну приналежність, містила загрозу зради нації (на противагу піднесенню українськості в XIX ст. як способу консоліАування націонацьної ідентичності). 
Інакшість Маври поєАнує образ примарної інцестуальної матері з iii спокусливістю. Показова в цьому сенсі сцена відвіАування Грицем іiі колиби-бурдею, який зображено як типовий бордемь, а саму Мавру як досвідчену стару повію. Вона показує танець, яким заробляла гроші й через який занапастила свою долю (він призвів до зачаття «білої» дитини). На цей танець «опущеної» жінки, яка «намагалася вдоволити його $[$ Гриця. - O. A.] всім найкращим, що Аише знала» $[5,430]$, хлопець не може дивитися без сорому. Виснажена Мавра падає на долівку, а Гриць платить їй. Зрештою, оскільки Гриць - біологічний Маврин син, а Тетяна - iї духовна дочка, стосунки між хмопцем і дівчиною теж можна вважати інцестуацьними.

БАизькість між старшою досвідченою жінкою і молодим хлопцем часто поставала центральним мотивом ранніх модерністських творів. Уперше ця тема з'явилася в «Месьє Венусі» Рашильди, в українському модернізмі ії можна знайти, наприклад, у романі Володимира Винниченка «Чесність з собою». Тут поєднано Ава концепти: віАповідальність Єви за первородний гріх та інцестуальну природу жінок. У повісті О. Кобимянської наявний останній аспект: Мавра, мати і спокусниця, палає бажанням до молодого хиопця, свого сина. Письменниця зробила своїх протагоністів циганами, маніфестуючи процес занепаду раси й національної кастрації.

У центрі «грішного» жіночого архетипу - належність жінки до чужинського етносу як найнебезпечніший елемент і з антропологічної, і з психоанацітичної перспективи. Загроза інцесту додається до проникнення представників інших етносів у громаду українців та небезпеки міжетнічного змішання - деконструкції історичної чи біологічної «реальності». Проте якщо згадати теорію КАода $\Lambda$ еві-Стросса про те, що табу на інцест виникмо Аля того, щоб «заохотити» екзогамію, помітною стає параноїдальність страхів «культурного й національного геноциду»: вірність Аиш одній нації чи культурі обертається на суїцидальну жагу.

\section{Незбагненна сатаниия, блюзнірська горгона, цинічна отруйниця}

У повісті Михайла Яцкова «Блискавиці» (1913) протагоністку — єврейку Альву Серпенс - наділено демонічною природою через «зміїне» прізвище (serpens з мат.: змія). «Альва» староєврейською має Ава значення: кистя і нечестивість, беззаконність. Отже, в імені та прізвищі героїні синтезовано алюзії на горгону, образ дерева, нечестивість та змію,

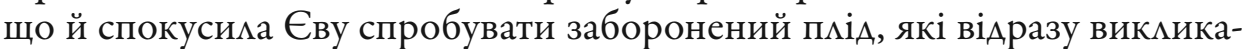
ють асоціацію з міфологемою первородного гріха (зв'язок між Євою та образом femme fatale розглянуто в праці Карен ЕдварАс [21]). Їі зрада Адама і Бога, що свідчить про єретичність жінки, принесла у світ смерть [Аив.: 16, 58]. Прикметно, що А^ьва пересувається по-зміїному, зви-

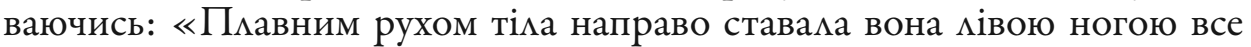
на п’яту, стопа опадала криво досередини, Альва скручувалася [курсив мій. - O. A.] наліво і ставаца правою стопою просто напереА» [15]. 
Жіночий образ у творі М. Яцкова перегукується не тільки з тематикою нечестивості й смерті. Він також репрезентує прокмяту або про-

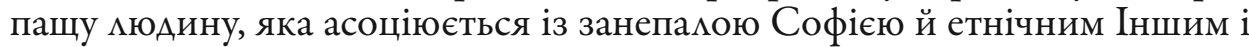
має конотації сексуацьності та трансгресивності. У тих випадках, коли нечестивість метонімічно пов'язувацася із жінкою-протагоністкою, моАерністи зазвичай поєАнували сатану-спокусника (головного підбурювача гріха) із жіночністю й описуваци жінок, використовуючи зміїну образність і мотиви первородної непорочності (непорочності чоловіків), отруєння, розпусти, вини, зокрема за здійснення інцесту, і покарання. Жіноча нечестивість пов'язана з сексуальністю й асоціюється із забороненою, диявольською або вампіричною жагою, з гріхами пцоті.

У творі М. Яцкова сатана-спокусник пов'язується не тільки з розбещеною, отруйною жіночністю, а й з етнічною інакшістю героїні, небезпекою деевоцюції, націонацьної дегенерації, яку вона втілює. Альва нічим не примітна, нудна, аце водночас зловісно таємнича та відьомська, iї образ ототожнюється з декадентською естетизацією гріха, пороку і смерті. Г. Грабович наголошує, що образ віАьми народжується саме «зі стику жіночого й чоловічого, з того таємничого й непізнаного простору, з якого ми всі беремося» $[2,277]$. Андрогінне єство Альви корелює 3 «прихованою відьмою», що криється в ній. Показна асексуальність і безпліАність жінки на початку твору апелює до вампіричної і змїної образності. А^ьва стереотипно вдається до самоприниження і представ ення себе як слабкої жінки, змінюючи уявлення про силу і владу. За цією «слабкою» особистістю проступає femme fatale, ще більш маніпулятивна й небезпечна. Ця свідома самопрезентація особливо насторожує, оскільки приховує нерозгаданість Іншої, ії єретичну демонічність.

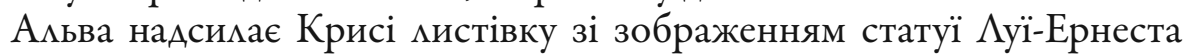
Барріа «Квітка зими», яка уособлює типову репрезентацію єврейської жінки в християнській іконографії - переможеної синагоги. Обираючи зображення не дуже відомої скульптури замість всесвітньо знаного шедевра $\Lambda$.-Е. Барріа «Природа, що розкривається перед наукою», Альва насміхається з цієї іконографії, вона асоціює себе з «Квіткою зими», використовуючи стереотипну мову Аля опису єврейської жіночності: слабкої, терпмячої, переможеної, нежіночної (у скульптури маленькі нерозвинені груди). Криса запитує А^ьву, яку пору року вона мюбить найбімьше, на що та відповідає, що мюбить «лише зиму». Він здивовано реагує:

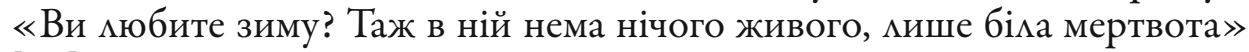
[15]. Криса не здатен зрозуміти, що А^ьва глузує наА стереотипами, і сам реагує стереотипно, кажучи, що «гарна, біла, струнка різьба - символ бездольної Альви» [15].

Справжнє значення «Квітки зими» криється у ії французькій назві - «Fleur d'hiver», яка означає отруйну квітку аконіт. За мегендою, коли Геракц звільнив з Аїду монстра-пса Цербера, того осліпило яскраве сонячне проміння і з пащі почала капати слина. На тих місцях виросли отруйні квіти. Тобто загрозцива і вбивча суть Ацьви прихована «піА землею», і тільки слина скаженого пса, яка ії окропить, здатна по- 
справжньому запціднити і пробудити потаємну отруйність. НевипаАковим у тексті є такий епізод: коли Криса цікує А^ьву, він порівнює ії поцікунок із питтям із «затруєної чарки», іiі ж посмішка «труйна», a таємничість «як чар отруї». Спокусмивий, збочений еротизм, метонімічний щодо змії / вампірки / отруйної квітки, у модернізмі зазвичай пов'язується з отрутою, прокмяттям і передачею первородного гріха через укус зміі та куштування забороненого плоду; він симвоцізує потрапляння в заманцивий, заборонений, фатальний полон.

Образи горгони, вампірки та отруйної квітки увиразнюються звуками: Ацьва сміється «горцяним ацьтом», «в ії горлі грає кцарнетовий сміх . Нечестивість виражається також у їі «східному» акценті, з характерним гаркавим «р», яке Аратує Крису (він порівнює цей звук із карканням). Спотворення і «забруднення» мови - звичний компонент у зображенні євреїв.

Мотив отруйності та відразцивості з'являється і в описах Альвиної усмішки: вона «солодко-квасна», «солодкаво-труйна». Інакшість і гібридність героїні водночас віАвертають і зачаровують Крису. Він усе більше ненавидить себе, коли розуміє, що безсилий перед чарами цієї нечестивої, огидної й таємничої жінки. 3-під маски «слабкої» Ацьви чітко прозирає femme fatale, iї все важче зрозуміти в непереборній інакшості:

Іскра з хоровито м'ягкого рамена одурювала його, блідий профіль Альви тремтів, iii око слідило Крису хитро з-під брів понад цвікер. ...що криється піА тим оком? Раз було воно полохливе, непевне, підзорливе, фальшиве, то за хвилю гляділо в нього зі студеною грозою, і йому здавалося, що коли 6 позволив собі на свобіАнійший крок, то в ту мить блиснув би ніж або револьвер коло його груАі або щонайменше - могла би вона кинутися на нього, як мюдина, яка попала в острий шал. <..> Тайна сеї дівчини зачала притягати його, як чар отруї. <...> Був в них [в iї очах. - O. A.] скритий, солодко-квасний усміх, який притягав Крису, як зачарований напій [15].

Марія Ревакович наголошує, що Крисина нав'язлива зачарованість Ацьвою виражається у фетишистському бажанні розчценувати іiі тіло $[11,31]$. Криса долає почуття національної гідності, закохавшись у єврейку і навіть вважаючи ії фізично й інтелектуально привабливою, називає iï своєю музою: «Аоповнюєш таємні недостачі в моїм організмі. В тобі моя мірична, хора жадоба» [15]. Те, що Криса-письменник надихається «чужинською» жіночністю, підтверджує спостереження С. Павиичко: в контексті української Аітератури жіночність стає синонімом і Ажеремом модернізму, адже в них обох $є$ гендерна пиинність і підважено ідею стабільної етнічної належності $[10,70]$. Етнічна жіноча інакшість стає необхідним доповненням до маскулінної українськості, яка одночасно жахається їі, аце й потребує Аля свого розвитку та розмаїття.

Унаслідок цього перевертання стереотипів іншована й демонізована жіночність несподівано набирає сили. Попри те що Альву напочатку було зображено як андрогіна (це актуацізує мотиви не тільки націонацьного, аце й гендерного розхитування, притаманних модернізму), після першого сексуацьного контакту Криса відкриває красу ії тіла: «Окса- 
митні рамена і шия упокоюваци його. <..> Аивувався, що тих ніжних, прегарних міній не догадувався навіть у неї ніколи» [15]. Коми Ацьва роздягається, Криса бачить у ній «скарб краси, живий, сердечний твір його Ауші». Він «вАивлявся в неї, як в цвіт мотоса» [15]. Це перетворення отруйної квітки на Аотос, симвоц творчості, свідчить не тільки про евоцюцію образу Ацьви, а й про еволюцію чужинської жіночності в модернізмі загалом.

Альвині гермафродитизм та андрогінність корелюють з їі «дитинним» єством: Криса не сприймає ії як жінку й жахається ії ще не проявлених якостей. Зв'язок Аитинності, андрогінності та жаху невідомого апелює до теорії архетипів Карла Густава Юнга, за якою дитина постає як видіння та проявлене несвідоме. К. Г. Юнг називає потенційний жах «стадією мямечки», з якої має «вимупитися» загрозмива істота $[14,206]$. Учений зазначає, що «образ дитини... частіше розвивається на основі цілком нехристиянських попередніх сходинок - із тварин піАземного царства. $<. . .>$ У снах вона [Аитина. - 0. .. .] іноді навіть екзотичного походження» $[14,207]$. ААьвина «зміїність» також цілком віАповідає Юнговій теорії, за якою образ дитини проявляється як гном або ельф, що демонструє ії приховані сили $[14,205]$.

Спосіб конструювання жіночої етнічної інакшості Ацьви стає загрозою Аля Криси, оскільки виявцяє зраду традиції, стимулюючи маскулінну культуру, яку втілює Криса, постійно контролювати і керувати жіночою сексуальністю, схицяючи жінку до вірності домінантним наративам. Проте Криса радше безпорадно намагається відновити контроль. Саме

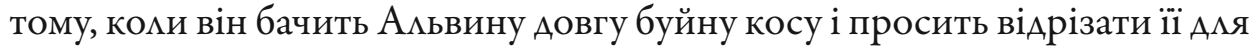
себе, вона Аає йому це зробити, бо залишається байдужою до символічної системи, в якій перебуває Криса і віА якої дистанціюється модерністське світовідчуття, втілене в образі Альви. КАіше щодо позбавлення сили чи жіночої привабливості через відрізання волосся підкреслюється ще раз, коли Криса вкцадає пасмо в альбом із картинами Обрі Бердслі, одним із головних мотивів яких була диявольська жіноча краса, яку герой намагається знешкодити, каструючи.

Подвійна природа А^ьви додається до багатошаровості їі образу, в якому поєАнуються черниця і блудниця. Коли Криса думає про неї, то уявляє святою: «Пригортав тінь ААьви, ніжно, як з’яву святої» [15]. Ба більше, він зізнається у своїх стосунках з нею Аружині й Ользі. У таких сценах А^ьву репрезентовано як морацьний авторитет, що мегітимізує iï інакшість, щоб переосмислити й утвердити іiі святу жіночу сутність шляхом встановлення нового, трансформованого «порядку». У цьому «теургічному» акті зАамано й пересотворено попередні уявцення про А^ьвину сексуальність, жіночність, гріховницьку етнічність, а також суміжні поняття нечестивості й етнічної мояльності.

Коли Альва байдужіє до Криси, це вражає його Его. Ще раз їі зустрівши, він знову думає про те, що «вона була квасна..., бездушна, як кожда жидівка» [15], і пахне жінка вже не як мотос, а як єврейська кухня («порохно, риба і гвоздика»), до того ж вона має риб’яче тіло й рухається як 
змія. Отже, Ацьва постає загрозою особистісній та колективній ідентичності, а їі зміїність тільки підсилює цю небезпеку, бо коли Ажерело страху «походить з боку драконів чи змій, то це вказує на загрозу поглинути все те, що набула свідомість $>[14,216]$. В імпресіоністській фінальній сцені Криса повертається до націонацьних цінностей, як блудний син звертається до братів і сестер, Ао своєї землі та природи, ніби вони можуть врятувати його або зупинити крах рас і націонацьностей.

\section{Ненаситна демоничя, кровопивичя, кастраторка}

Художні твори жінок часто поставали як реакція на мізогінне бачення жіночності в андроцентричній традиціі. Розглянемо татарську жіноч-

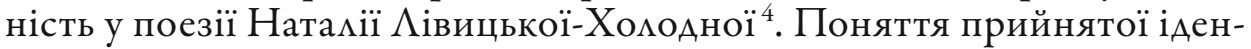
тичності ця поетка розширица до особистих реацій, наголошуючи на в $а$ асному татарському походженні й приписуючи йому чаклунство та нечестивість. Вона осмислюваца гендер і творчість крізь призму татарської іАентичності. Негативні образи жінок у Н. Аівицької-Холодної можна вважати результатом соціокультурної інтернацізації домінантного метатексту. Попри те що їі поезія поверхово узгоджується 3 типовими адроцентричними наративами, вона підриває нав'язаний образ жіночності та створює простір Аля самосвідомої жіночої міфомогії. Специфічна адаптація татарської ідентичності стала політично й релігійно мотивованим актом, який підривав і руйнував пануючу православну традицію.

Прапрабабуся Н. Аівицької-Холодної була дочкою татарського мірзи, іiі покохав прапрадіА поетки, одружився з нею і привіз у Полтаву $[7,73]$. Н. Аівицька-Холодна вдається до подвійної екзотизації: їі героїня поєАнує характеристики демонічної сотниківни і спокусливої татарки, наприкцаА, у вірші «На розквітлі акації грона...» $[8,72]$. Образ сотниківни нагадує молоду відьму в Гоголевому «Вї», а от подвійна українськотатарська ідентичність укорінена в автобіографічному минулому: предки Н. Аівицької-Холодноїбули татарами та українцями. Останні очолювали сотню в $\Lambda$ іплявому, а їхній маєток називався Сотницьке. Місцеві кциками Аівицьких Сотниченками. Матір поетки наголошуваца, що нащадки цього міжетнічного шиюбу були дуже гарні [7, 69-73]. Таке продуктивне змішання української й татарської ідентичності, доповнене не тільки фольклорними й міфологічними конструктами, а й квазібіографічними фактами, поєАнує методи самоорієнтацізації поетки з ії піАривом андрота етноцентричної традиції, яка завжди надаваца перевагу етнічній визначеності й чистоті.

Акцентування у поезї Н. Аівицької-Холодної на вампіричній / татарській інакшості (а отже, свідомій варварській нехристиянськості) пов'язано з відчуттям жаху й постійної загрози забруднення крові та на-

\footnotetext{
${ }^{4}$ Моє дослідження фемінності у поезії Н. Аівицької-Холодної “The Theurgy of Impurity: Fin-de-Race and Feminine Sin in Russian and Ukrainian Modernisms" надруковано в журналі “The Russian Review” (78-3 (2019), с. 459-485).
} 
ціональної / расової кастрації. Єретична протагоністка, яка поєднує в собі вампірку-татарку й українку-відьму, має чорну кров і жахливо білі зуби, а їі чарівцивий голос породжує «криваві кошмари»:

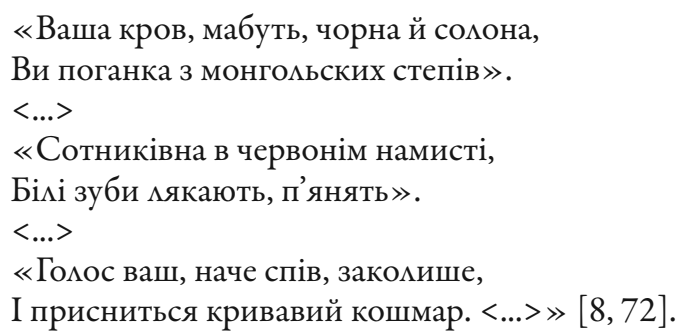

Така українська екзотичність у мітературі апелює до псевдоорієнтальних чи загалом «азіатських» гібридних рис. Парацельно з суто фізичним орієнталізуванням української краси існувало історичне сприйняття жінок-українок як сильних і войовничих степових амазонок. Цей погляд закріпився в міфі про матріархат і посилився завдяки актуалізації пам'яті про поганські культи, у центрі яких фігурували жінка й матір.

У дослідженнях європейської мізогінії було простежено зв'язок між образами жінок-вампірок і змій, сексуацьності й смерті [20, 333-352; 27, 199-216]. Вампіричні мотиви в поезії Н. АівицькоїХолодної символізують сексуальний фетиш і репрезентують сексуальне задоволення протагоністки [12,29-30]. У ї віршах жінку преАставлено як цинічну, розпусну татарку-кровопивицю, чиї виразно демонічні характеристики нагадують про занепалу Софію, Єву та вампірок. Традиційний образ жінки-вампірки набуває сексуальності в смертельно-карнавацьних актах, іï метафорично пов'язують із жагою гріха й одночасно - 3 венеричними хворобами. Вампірка, створена, щоб руйнувати репродуктивну зАатність Аюдини, - це один із головних тропів декадансу.

Серед найважливіших у поезії Н. Аівицької-Холодної - мотив спокуси і хтивості, коли жінка набуває характеристик спокусниці-змії, вампірки, сексуально ненаситної демониці. Через нібито вроджену розпусність жінки ії преАставцено в модернізмі як диявольську спокусницю, образ, що давно сформувався в канонічних юдейських та християнських текстах (Єва, Саломея, Юдит, Аеліла), а також в елміністичній та римській культурах (Пандора, Медея, Клодія, Ксантиппа), забезпечивши модель Аля мізогінної міфології, інтерналізованої авторками-жінками. Ця образність стаца основою Аля стереотипного зображення жінок як спокусниць у живописі та скульптурі, Ае показано сексуально привабливих і доступних дріад і ореад, дерев, прикрашених жіночими тіками, які запрошуваци до сексуацьного контакту або навіть «терапевтичного гвацтування» $[20,109]$.

Традиційний образ вампірки сексуалізувався через співпричетність Ао смертельного акту й зазвичай сполучався з фігурою спокусниці, но-

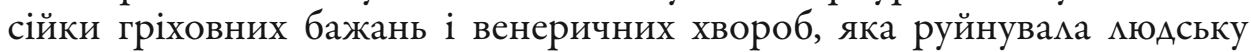
репродуктивність. Образ зміі, яка спокушає, затягує, висушує чоловіче тіло, репрезентовано у цьому вірші Н. Аівицької-Холодної: 
Будеш завжАи цю ніч пам'ятати,

Не забудеш, о ні, моїх уст,

I цвістимуть, цвістимуть шар аати

В твоїм серці вогнями спокус.

$<\ldots>$

Та Аарма, я гадюкою стисну,

Я візьму з твого серця всю кров $[8,72]$.

Чоловік, який не розділяє почуттів жінки, потрапмяє в полон до владної протагоністки-вампірки, котра змушує його до інтимних стосунків і чиї спокусливі пурпурові вуста мучитимуть його вічно. Таку силу жінці й сексуальне безсимля чоловікові забезпечують демонічні якості, якими володіє жінка. Чоловік не зможе втекти, бо ця горгона / вампірка / згубна квітка витискає з нього і вбирає в себе життєдайну енергію, фактично гваАтуючи його.

Образ вампіричної femme fatale, фігури одночасно активної, сексуальної, етнічно чужої та змовісної, простежується у європейській мітературі. Французькі символісти (особливо Шарль Болмер, який вплинув на творчість Н. Аівицької-Холодної) зазвичай наділяли жінок рисами хтонічних істот, змій.

У творах Н. Аівицької-Холодної мотив спокуси пов'язаний із криваво-червоним або мертвотно-синім ротом героїні. Спокусмивий, збочений еротизм асоціюється 3 отрутою, прокмяттям і переданням первородного гріха через укус змії та куштування забороненого плоду й символізує потрапмяння безсилого чоловіка в заманливий, заборонений, фатальний полон. Смертельний екстаз під час сексуального акту у творах поетки пов'язаний з кров'ю, демаскулінізацією, занепадом, зокрема національним, а отже, і з кастрацією, вихолощуванням та фетишизмом.

В інших поезіях спокуслива сексуальність вампірки аналогічно втіюється у квітучій отруйній плоті, яка нагадує вагіну, що стікає менструальною кров'ю, або в синій, безкровній, ніби мертвій плоті, яка виявляє бажання наповнитися кровю чи запліднитися життедайною рідиною, що натякає на ненаситну жіночу сексуальність. Показовими у цьому контексті $є$ такі поетичні фрагменти:

\section{Я тобі принесла фіялки 5 , \\ А як місяць наА містом став, \\ Ти мене цікував так палко \\ У розквітлі мої уста $[8,67]$}

Вогнями пристрасти цвітуть

Уста мої широкі й повні.

$\mathrm{O}$, ти не зможеш їх забуть,

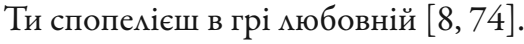

БАіді були твої уста,

А в мене защвіли шарлатом $[8,68]$.

В мене сукня була червона,

\footnotetext{
5 Тут і далі курсив мій. $-O . A$.
} 


\section{А уста защвіли тюльпаном, \\ I на них була кров солона, \\ Твоя кров, з твоїх уст, коханий $[8,73]$.}

Така квіткова образність в культурі співвідноситься із чоловічим страхом «спокуситися на жіночу оргазматичну силу» й наразитися на небезпеку «бути осушеним іiі маточками, які прагнуть запліднення» [20, 241]. Варто відзначити, що ранній псевдонім Н. Аівицької-Холодної був Наталка Волошка. Образ квітки, яка все поглинає і всотує, перегукується з образом зубастої вампірки й актуалізує в пам'яті архетипний образ vagina dentata: за античним народним віруванням, у вагіни $є$ зуби і сексуальний акт може загрожувати чоловікові кастрацією [Аив.: 30, 163-183]. У цитованих поетичних фрагментах жінка репрезентує себе як сексуалізовану, демонічну істоту, яка має силу не тільки спокусити чоловіка й вимагати віА нього сексуальної взаємності, а й виснажити й каструвати його.

Темататарськоїєретичностінадзвичайно актуальнавпоезіїН. АівицькоїХолодної. Татарка цілує, отруює і вбиває свого молодого коханця:

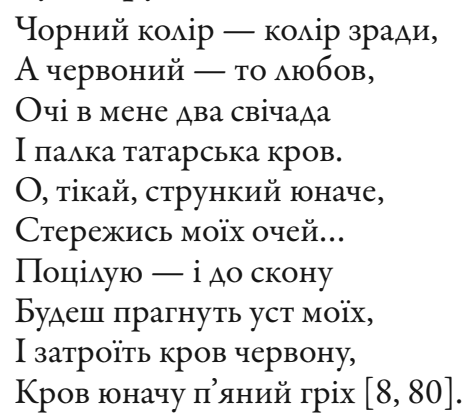

Єретичність цієї сексуально ненаситної особи поглиблює мотив етнорелігійного Іншого і стає Ажерелом додаткової тривоги, пов'язаної з сексуальністю, страхітливою і водночас демонічно привабливою завдяки своїй екзотичності. Вона корелює із зображенням примарної інцестуацьної матері з їі спокусливими та смертемьними обіймами. Жіноча єретичність відображена паралельно із жіночою гріховністю у вірші «Гріх». Ао гріха героїню спонукає ії татарська кров:

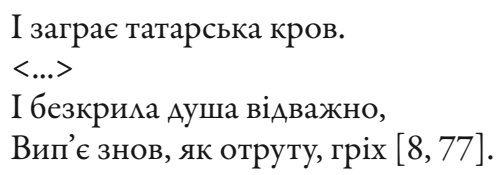

У поетки виникають описи себе самої, які провокативно закучають мізогінний і етнофобний / єретичний символізм. Таким чином авторка хоче наголосити на усталених міфологічних категоріях Іншого й переосмислити, а подекуди і скасувати їх. Вона постає одночасно у трьох іпостасях: жінки, татарки і єретички, на яку «нормативний», православний чоловічий дискурс спрямовує свою силу заради самозбереження.

Сучасники Н. Аівицької-Холодної реагували на їі автобіографічний образ як жінки-чужинки, Аолучаючи до цього особливості самоміфотворення поетки як сексуально неприборканої та смертельно загрозмивої та- 
тарки. Євген Маханюк зазначав про поєАнання образу татарки і мотиву жіночої зради в поезії Н. Аівицької-Холодної (він присвятив письменниці окремий цикл віршів «Псальми степу»). За Аопомогою епіграфа зі «Слова про Ігорів похіА» Є. Маланюк пов'язує поетку з половецькою / татарською загрозою:

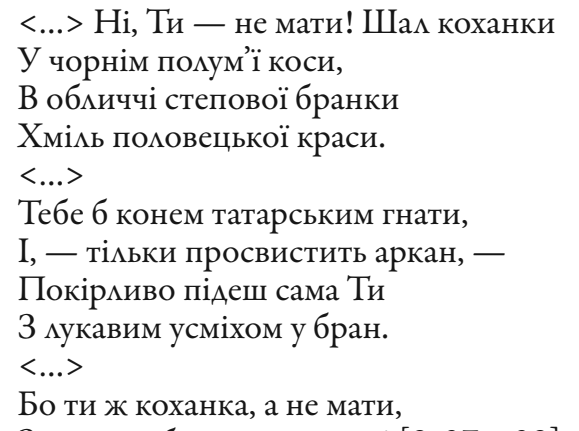

У цьому вірші демонічна сексуальність і жіноча руйнівна сила увиразнені сприйняттям татар як агресивних, непокірних і ненадійних. Цей образ накладається на зображення Єви як першої єресіархині та зрадниці Бога й ААама. Розглядаючи жіночу зраду в культурі як форму піАриву репресивного маскулінного авторитету, вчені ототожнюють эі з віАмовою віА використання традиційної символічної мови. Окрім того, на таку зраду етнічно інші жінки здатні з метою руйнування солідарності чоловіків і загалом нації [Аив.: 18, 3].

У цитованому вірші жінка - половчанка (татарка в цьому контексті), асимільована в українську культуру (тут можна вбачати алюзію на прапрабабу поетки, а також на ії непокірну прабабу з того ж татарського боку, яка жила окремо від чоловіка в іншому маєтку $[7,73])$. Наголошено на найважмивіших пунктах — неукраїнському походженні протагоністки та їі відповідній зовнішності (чорна коса, екзотична врода), а також на iі готовності зрадити, повернутися до татар.

ПоєАнання гендеру з етнічною приналежністю та гетеродоксією мало значний вплив на модерністський дискурс жіночності, що проявилося в розхитуванні фалоцентричної традиціі. Аспекти інакшості (а саме: гендер і етнос), що репрезентовані в єврейській, татарській і ромській ідентичностях протагоністок, об'єАнацися в категорію демонічного Чужого і містять загрози єретичності, екзогамії та націонацьної кастрації. Це не тільки небезпека біологічного занепаду панівної та гомогенної слов'янської православної маскулінності, а й страх перед посиленням та домінуванням Іншого (гендерного та етнічного), перед загрозою його культурної інтеграції та вцаАної переваги. Жіночність, гомосексуальність і належність до іншого етносу пов'язувацися з фізичною єрессю, насимьством і вампіризмом. Міркуючи про психологічні мотиви популярності теми вампіризму в $і$ ітературі fin de siècle, Брам Аейкстра стверджує, що поняття «расового кровозмішання» та його страху пов'язувацося з такими семантичними паралемями, як жінка / вампір, андрогін / гомосексуац 


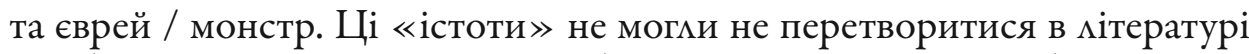
на вбивць та передвісників епохи бездітності, яка неминуче би приводима до занепаду будь-якої нації $[19,183]$. Очевидно, що звертання до теми етнічних чужинців і єретиків, які в тогочасному європейському контексті співвіАносилися з жіночим вампіризмом і нечестивістю, - наслідок того, як у модерністській мітературі зображувацася жіночність.

В українській модерністській культурі мізогінність посицювалася етнофобними настроями та демонізуванням Іншого. Провокативна і принципово опозиційна до попередніх традицій естетика модернізму виявимася деструктивною і до етнічного Аискурсу. Багато авторів екстраполюваци ці тенденції у власну творчість, перенісши їх із маргінесів пубцічного дискурсу в його осердя (М. Шкандрій пише про тенденції позитивізації образу єврея в $\Lambda$ ітературі модернізму та самокритичні щодо націонацьної свідомості позиції деяких митців доби $[28,90])$. На ці зміни також вплинуло трактування теми неоднозначності та некогерентності етнічності та гендеру в естетиці модернізму. Тому українську вроду - екзотизовану й надікену рисами femme fatale ще в романтичному топосі, культивованому імперською Аітературою, - було змішано з екзотичністю та демонічністю етнорелігійної орієнтацьної жіночності. В українському модернізмі жіночність наділено більшою силою завдяки етнічній інакшості: жіночність як чужість здобула власний голос унаслідок мітературного переоцінювання фемінності. У творах, про які йшлося, виражена чужорідна жіночність $\epsilon$ провідною темою, яка провокативно апемює до патріархацьних страхів етнічного виродження, кризи слов'янської репродуктивності та маскулінності, переосмислюючи їх. Це знаменує перехідний етап на шляху від ієрархічної культури до нових форм гендерних та етнічних репрезентацій i їх рецепцій. Аналізовані твори не мише засвідчують тематичну схожість, вони також відображають спроби початку XX ст. піАважити етно- та анАроцентричний монокультуралізм.

Висловлюю подяку Антоніні Яиук за допомогу з перекладом статті, Максиму Тарнавському і Тамарі Гундоровій за сприяння в роботі над дослідженням, а також Валентині Вздульській за редакторські зауваги.

\section{МITEPATУPA}

1. Грабович Г. Ао історії української мітератури: АосліАження, есе, полеміка. Київ: Основи, 1997. 608 с.

2. Грабович Г. Тексти і маски. Київ: Критика, 2005. 312 с.

3. Гундорова T. Femina melancholica. Стать і культура в гендерній утопії ОАьги КобиАянської. Київ: Критика, 2002. 272 с.

4. Гундорова T. ПроЯвлення Слова. Аискурсія раннього українського модернізму. Київ: Критика, 2009. 448 с.

5. Кобилянська О. В недімю рано зілмя копала // Кобилянська О. Зібрання творів: У 2 т. Т. 2. Київ: Аніпро, 1988. С. 295-471.

6. Крамар Є. Аослідження з історії України. Торонто: Смолоскип, 1984. 187 с.

7. Аівицька М. На грані двох епох. Нью-Йорк: Комітет, 1971.335 с.

8. Аівищька-Холодна Н. Поезії, старі і нові. Нью-Йорк: Видання Союзу Українок Америки, 1986. $238 \mathrm{c.}$ 
9. Маланюк $Є$. Поезії в одному томі. Нью-Йорк: НТШ в Америці, 1954. 299 с.

10. Павличко С. Аискурс модернізму в українській мітературі. Київ: Аибідь, 1999. 447 с.

11. Ревакович $M$. Аекадентські мотиви в українському романі fin de siècle: Агатангел Кримський та Михайло Яцків // Slavica Wratislaviensia. 2011. Том 154. С. 21-34.

12. Рубчак Б. Серце надвоє роздерте // Аівицька-Холодна Н. Поезії, старі і нові. НьюИорк: ВиАання Союзу Українок Америки, 1986. С. 3-56.

13. Сукаленко T. Типаж «циган» крізь призму українських прислів”їв та приказок // Аітература та культура Полісся. 2016. Вип. 82. № 6. С. 241-253.

14. Юнг K. I. Архетипи і колективне несвідоме. $\Lambda$ ьвів: Астролябія, 2018. 608 с.

15. Яиків М. БАискавиці. URL: http://sites.utoronto.ca/elul/Iatskiv/Blyskavytsi.html (15.03.2021).

16. Arbel $V$. Forming Femininity in Antiquity: Eve, Gender, and Ideologies in the Greek Life of Adam and Eve. New York: Oxford UP, 2012.232 p.

17. Beauvoir S. The Second Sex. New York: Knopf, 1964.732 p.

18. Bow L. Betrayal and Other Acts of Subversion: Feminism, Sexual Politics, Asian American Women's Literature. Princeton UP, 2011.240 p.

19. Dijkstra B. Evil Sisters: The Threat of Female Sexuality and the Cult of Manhood. New York: Knopf, 1996. 480 p.

20. Dijkstra B. Idols of Perversity: Fantasies of Feminine Evil in Fin-de-Siècle Culture. New York: Oxford UP, 1986. $453 \mathrm{p}$.

21. Edwards $K$. The Mother of All Femmes Fatales: Eve as Temptress in Genesis 3 // Helen Hanson, Catherine O'Rawe (Eds.). The Femme Fatale: Images, Histories, Contexts. Basingstoke, 2010. P. 35-45.

22. Gilbert S., Gubar S. Introduction // Gilbert S., Gubar S. (Eds.). The Female Imagination and the Modernist Aesthetic. New York: Gordon\&Breach, 1986. P. 1-5.

23. Gilman S. Difference and Pathology: Stereotypes of Sexuality, Race, and Madness. Ithaca: Cornell UP, 1985. 292 p.

24. Gilman S. Salome, Syphilis, Sarah Bernhardt and the 'Modern Jewess' // German Quarterly. 1993. № 66/2. P. 195-211.

25. Irigaray L. Speculum of the Other Woman. Ithaca: Cornell UP, 1985.365 p.

26. McQuillen C. The Modernist Masquerade: Stylizing Life, Literature, and Costumes in Russia. Madison, Wisconsin: The University of Wisconsin Press, 2013.282 p.

27. Senf C. Daughters of Lilith: Women Vampires in Popular Literature // Leonard Heldreth, Mary Pharr (Eds.). The Blood is the Life: Vampires in Literature. Bowling Green, Bowling Green University, 1999. P. 199-216.

28. Shkandrij $M$. Jews in Ukrainian Literature: Representation and Identity. Yale UP, $2009.265 \mathrm{p}$.

29. Tarnawsky M. Feminism, Modernism and Ukrainian Women // Journal of Ukrainian Studies. 1994. № 2. P. 31-41.

30. Vachhani $S$. Vagina Dentata and the Demonological Body: Explorations of the Feminine Demon in Organization // Pullen A., Rhodes C. (Eds.). Advances in Organization Studies. Malmo: Liber, 2009. P. 163-183.

31. Yermolenko G. Tatar-Turkish Captivity and Conversion in Early Modern Ukrainian Songs // John Watkins, Kathryn Reyerson (Eds.). Mediterranean Identities in the Premodern Era: Entrepôts, Islands, Empires. London: Routledge, 2016. P. 191-209.

\section{REFERENCES}

Отримано 28 квітня 2021 .

1. Hrabovych, H. (1997). Do istorii ukrainskoi literatury: Doslidzhennia, ese, polemika. Kyiv: Osnovy. [in Ukrainian]

2. Hrabovych, H. (2005). Teksty i masky. Kyiv: Krytyka. [in Ukrainian]

3. Hundorova, T. (2002). Femina melancholica. Stat $i$ kultura $v$ gendernii utopii Olhy Kobylianskoi. Kyiv: Krytyka. [in Ukrainian]

4. Hundorova, T. (2009). ProIavlennia Slova: Dyskursiia rannioho ukrainskoho modernizmu. Kyiv: Krytyka. [in Ukrainian] 
5. Kobylianska, O. (1988). V nediliu rano zillia kopala. In O. Kobylianska, Zibrannia tvoriv (Vols. 1-2, Vol. 2; pp. 295-471). Kyiv: Dnipro. [in Ukrainian]

6. Kramar, Ye. (1984). Doslidzhennia z istorii Ukrainy. Toronto: Smoloskyp. [in Ukrainian]

7. Livytska, M. (1971). Na hrani dvokh epokh. New York: Komitet. [in Ukrainian]

8. Livytska-Kholodna, N. (1986). Poezii, stari i novi. New York: Vydannia Soiuzu Ukrainok Ameryky. [in Ukrainian]

9. Malaniuk, Ye. (1954). Poezii v odnomu tomi. New York: NTSh v Amerytsi. [in Ukrainian]

10. Pavlychko, S. (1999). Dyskurs modernizmu v ukrainskii literaturi. Kyiv: Lybid. [in Ukrainian]

11. Revakovych, M. (2011). Dekadentski motyvy v ukrainskomu romani fin de siècle: Ahatanhel Krymskyi ta Mykhailo Yatskiv. Slavica Wratislaviensia, 154, 21-34. [in Ukrainian]

12. Rubchak, B. (1986). Sertse nadvoie rozderte. In N. Livytska-Kholodna, Poezii, stari i novi (pp. 3-56). New York: Vydannia Soiuzu Ukrainok Ameryky. [in Ukrainian]

13. Sukalenko, T. (2016). Typazh "tsyhan" kriz pryzmu ukrainskykh prysliviv ta prykazok. Literatura ta kultura Polissia, 82(6), 241-253. [in Ukrainian]

14. Jung, C. G. (2018). Arkhetypy i kolektyvne nesvidome. Lviv: Astroliabiia. [in Ukrainian]

15. Yatskiv, M. Blyskavytsi. http://sites.utoronto.ca/elul/Iatskiv/Blyskavytsi.html. [in Ukrainian]

16. Arbel, V. (2012). Forming Femininity in Antiquity: Eve, Gender, and Ideologies in the Greek Life of Adam and Eve. New York: Oxford UP.

17. Beauvoir, S. (1964). The Second Sex. New York: Knopf.

18. Bow, L. (2011). Betrayal and Other Acts of Subversion: Feminism, Sexual Politics, Asian American Women's Literature. Princeton UP.

19. Dijkstra, B. (1996). Evil Sisters: The Threat of Female Sexuality and the Cult of Manhood. New York: Knopf.

20. Dijkstra, B. (1986). Idols of Perversity: Fantasies of Feminine Evil in Fin-de-Siècle Culture. New York: Oxford UP.

21. Edwards, K. (2010). The Mother of All Femmes Fatales: Eve as Temptress in Genesis 3. In Helen Hanson, \& Catherine O’Rawe (Eds.), The Femme Fatale: Images, Histories, Contexts (pp. 35-45). Basingstoke.

22. Gilbert, S., \& Gubar, S. (1986). Introduction. In S. Gilbert, \& S. Gubar (Eds.), The Female Imagination and the Modernist Aesthetic (pp. 1-5). New York: Gordon\&Breach.

23. Gilman, S. (1985). Difference and Pathology: Stereotypes of Sexuality, Race, and Madness. Ithaca: Cornell UP.

24. Gilman, S. (1993). Salome, Syphilis, Sarah Bernhardt and the 'Modern Jewess'. German Quarterly, 66(2), 195-211.

25. Irigaray, L. (1985). Speculum of the Other Woman. Ithaca: Cornell UP.

26. McQuillen, C. (2013). The Modernist Masquerade: Stylizing Life, Literature, and Costumes in Russia. Madison, Wisconsin: The University of Wisconsin Press.

27. Senf, C. (1999). Daughters of Lilith: Women Vampires in Popular Literature. In Leonard Heldreth, \& Mary Pharr (Eds.), The Blood is the Life: Vampires in Literature (pp. 199-216). Bowling Green.

28. Shkandrij, M. (2009). Jews in Ukrainian Literature: Representation and Identity. Yale UP.

29. Tarnawsky, M. (1994). Feminism, Modernism and Ukrainian Women. Journal of Ukrainian Studies, 2, 31-41.

30. Vachhani, S. (2009). Vagina Dentata and the Demonological Body: Explorations of the Feminine Demon in Organization. In A. Pullen, \& C. Rhodes (Eds.), Advances in Organization Studies (pp. 163-183). Malmo: Liber.

31. Yermolenko, G. (2016). Tatar-Turkish Captivity and Conversion in Early Modern Ukrainian Songs. In John Watkins, \& Kathryn Reyerson (Eds.), Mediterranean Identities in the Premodern Era: Entrepôts, Islands, Empires (pp. 191-209). Routledge.

Received 28 April 2021 
Alex Averbuch, $\mathrm{PhD}$,

Izaak Walton Killam Memorial Postdoctoral Fellow

University of Alberta,

200 Arts Building Edmonton, T6G 2E6

e-mail: averbuchalex@gmail.com

ORCID https://orcid.org/0000-0003-0721-6958

\section{ORIENTALIZING FEMININITY: NOTIONS \\ OF IMPURITY IN UKRAINIAN MODERNIST LITERATURE}

The paper examines the interconnectedness of feminity with ethnonational otherness in Ukrainian modernist literature in the context of European misogyny and ethnophobia. It demonstrates how the representation of female sinful otherness, impurity, and disloyalty was cemented in misogynistic imagery, in which women appeared as witches and heterodox temptresses through sexual and cultural differentiation. The otherizing of Orientalized ethnic groups in Eastern Europe - typically Jews, Roma, and Tatars - involved their conceptual feminization as well. Specifically, the paper analyzes the topic of the decay of the Slavic/Orthodox/masculine 'race' and the range of concomitant tropes and ideas found in Ukrainian modernist literature, such as castration, celibacy, and obsession with 'tainted' blood, which reflected 'racial' anxieties that went hand in hand with misogynistic ideas of the feminine role in spiritual and physical decline. The study performs close readings of works by Olha Kobylianska, Mykhailo Yatskiv, and Natalia Livytska-Kholodna, in which women appear as demonic-vampiric, heterodox seductresses and heresiarchesses, who threaten to ruin the ethno-androcentric culture of the modernist epoch. Orientalized femininity and the ambivalence it brought to Ukrainian modernism harbored the ethnoreligious fears and inherent sinfulness that encompassed traditional descriptions of the femme fatale, as well as such associated figures as the fallen angel and seductive adulteress - the initiatrix of moral, sexual, national, and religious transgression, which invariably alluded to a perceived crisis in patriarchy and reproductivity. The analysis focuses on the three thematic aspects of sin and sinfulness: temptation, heterodoxy, and betrayal.

Keywords: ethnonational otherization, modernist literature, misogyny, women's writing, gender.

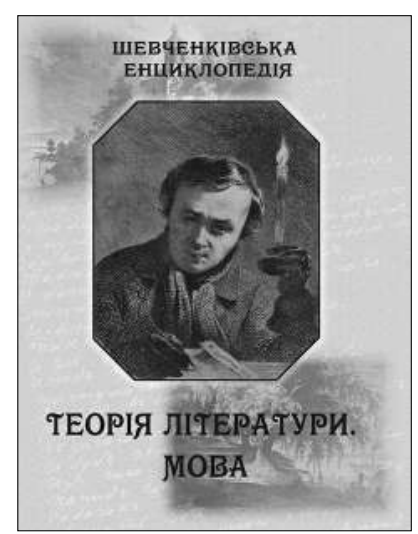

Наші презентаціï
Шевченківська енцикмопедія: Теорія мітератури. Мова / реА. колегія: М. Г. Жулинський (голова), М. П. Бондар, О. В. Боронь [та ін.]. Київ: Видавництво Аіра-К, 2021. 1108 с.

Видання підготовлено в Інституті Аітератури ім. Т.Г.Шевченка НАН України на основі відповідних статей шеститомної «Шевченківської енцикмопедії» (2012-2015). В одному томі зібрано розвідки, в яких комплексно досліАжуються скцаАні теоретико-літературні проблеми творчості Тараса Шевченка, ії провідні теми і мотиви, гомовні образи-концепти, а також жанри, питання поетики і мови, що в підсумку розкриває оригінальність художньої свідомості митця, його Ауховного світу й ціннісних орієнтирів. Порівняно 3 «Шевченківською енциклопедією» Аодано статтю Наталії Слухай «Міфологеми художньо-мовні». Наукове редагування здійснили Ніна Чамата, Валерія Смілянська та Роксана Харчук. Науковий консультант проєкту - Сергій Гамьченко. 